\title{
INSPIRASI AL-QURAN DALAM PEMBERANTASAN KORUPSI
}

\author{
Darlis \\ Institut Agama Islam Negeri (IAIN) Palu
}

\section{Abstract:}

Corruption is an extraordinary crime. The impact is not only threatening the life order of society but also can tear the national stability. In 2017, Indonesia is still in the order of 90 of 176 countries in the world who have an index of achievement in eradicating corruption. This means that corruption in Indonesia is still very large. With this fact, this paper elaborates the concept of the Quran relating to corruption and its prevention. Through the study of thematic-integrative commentary with maqshidi analysis, it is found that the word as-suhtu, ghulul and al-fasad are terms that describe the phenomenon of corruption in Al-Quan. While preventing corruption, the Koran alleges the death penalty for perpetrators of crimes that damage both natural resources, human resources and community order.

Keywords: Al-Quran, al-Suht, al-Ghulul, al-Fasad, Prevention, Corruption. the death penalty

Abstrak:

Korupsi adalah kejahatan yang luar biasa. Dampaknya tidak hanya mengancam tatanan kehidupan massyarakat tapi juga bisa mengoyak stabilitas nasional. Tahun 2017, Indonesia masih dalam urutan ke-90 dari 176 negara di dunia yang memliki indeks prestasi dalam 
pemberantasan korupsi. Artinya korupsi di Indonesia masih sangat besar. Dengan fakta tersebut, paper ini mengelaborasi konsep Al-Quran yang berkaitan dengan korupsi dan cara pencegahannya. Melalui kajian tafsir tematik-integratif dengan analisis maqshidi, ditemukan bahwa kata as-suhtu, ghulul dan fasad adalah termaterma yang menggambarkan fenomena korupsi dalam Al-Quan. Sementara pencegahan korupsi, Al-Quran mensinyalir hukuman mati bagi pelaku kejahatan yang merusak baik sumber daya alam, sumber daya manusia maupun tatanan masyarakat.

\section{Keywords: Al-Quran, al-Suht, al-Ghulul, al-Fasad, Pencegahan,} Korupsi, hukuman mati.

\section{Pendahuluan}

Korupsi merupakan kata yang sudah mengakar dalam sejarah manusia. Praktek korupsi sudah ada sejak manusia hidup dalam sebuah masyarakat di dunia secara terorganisir. Sejarah mencatat praktek korupsi sudah terjadi di Mesir Kuno, Babilonia, India, China, Yunani dan Romawi Kuno. ${ }^{1}$

Dalam konteks Indonesia, persoalan korupsi juga termasuk persoalan yang sangat besar dan tidak kunjung selesai. Pemerintah beberapa waktu yang lalu telah mengeluarkan ultimatum bahwa Indonesia darurat korupsi. Hal ini didasari oleh fakta bahwa angka korupsi di tanah air masih sangat tinggi. Menurut survey terkini, Transparency Internasional (TI), dalam kurun waktu lima tahun tahun, sejak 2011 sampai 2016, menempatkan Indonesia sebagai

\footnotetext{
${ }^{1}$ Hakim Muda Harahap, Ayat-ayat Korupsi, cet.I (Yogyakarta: Gama
} Media, 2009), h.8 dikutip dari Al-Andang L. Binawan, Korupsi (dalam cakrawala) Kemanusian (2006:xii-xiii). 
negara terkorup di urutan 90 dari 176 negara seluruh dunia. ${ }^{2}$ Meski ada peningkatan dari tahun sebelumnya, tapi perubahan itu belum terlihat signifikan. Bahkan dalam bidang tertentu masih berjalan di tempat, dan pemberantasan korupsi dilaksanakan secara setengah hati. Fenomena tersebut dapat disaksikan bagaiaman keterlibatan seluruh institusi kenegaraan dan kemasyarakatan dalam korupsi. Mulai dari lembaga terbawah, keluarahan, sampai dengan instansi tertinggi. Yang lebih tragis lagi, lembaga yang diamanatkan oleh undang-undang dan dipercayai oleh rakyat untuk memberantas korupsi, yang dikenal sebagai lembaga penegak hokum, justru terlibat korupsi. ${ }^{3}$

Atas dasar ini, makalah ini akan melihat kejahatan korupsi dari sudut pandang al-Quran. Bagaimana kata kunci Al Quran yang berbicara korupsi? Dan bagaimana inspirasi Al Quran dalam pemberantasan korupsi? Kedua poin itu menjadi konsen tulisan melaui kajian tafsir tematik-integratif dengan analisa tafsir maqhasidi. Namun, pertama kali penulis akan mendiskripsikan korupsi secara umum kemudian melihat tanggapan al-Quran.

\section{Permasalahan Korupsi}

Secara etimologi korupsi berasal dari bahasa latin, corruption, yang lahir dari kata corrumpere, berarti "busuk, rusak, menggoyahkan, memutar balik, menyogok". Oleh karena itu, Tranpararency International mendefinisikan koruspi sebagai "perilaku pejabat public, baik politikus/politisi maupun pegawai negeri, yang secara tidak wajar dan tidak legal memperkaya diri atau meperkaya mereka yang dekat dengannya, dengan

${ }^{22}$ https://luarotak.wordpress.com/2017/01/30/peringkat-korupsiindonesia-di-dunia-2017/ di akses pada hari Sabtu, 2 September 2017

${ }^{3}$ Abdullah Hehamahua, Jihad Memberantas Korusi, (Tangerang Selatan, EDUNEWS, 2017), h.xiii 
menyalahgunakan kekuasaan public yang dipercayakan kepada mereka". ${ }^{4}$ Sementara, Bibit S. Rianto memandang korupsi sebagai tindak kejahatan yang dilakukan oleh manusia yang melanggar suatu aturan hukum tertentu, yang kemudian merugikan diri sendiri, orang lain, masyarakat, bangsa bahkan negara. ${ }^{5}$

Hal itu senada dengan pandangan (Eigen,1997; Bardhan, 1997 dalam Mills 1997) bahwa korupsi adalah penyalahgunaan jabatan publik demi keuntungan pribadi (abuse of public official for private profit). Sehingga dalam pengertian di atas lebih mensinyalir praktek korupsi yang terjadi di kalangan birokrasi pemerintahan atau jabatan-jabatan publik. Sementara tindakan politik yang dikatakan oleh Bibit yang terjadi di sektor swasta, telah disinggung oleh (Eigen, 1997) juga sebagai penyalahgunaan tanggungjawab yang diterima demi keuntungan pribadi (ebuse of entrusted power for private profit). ${ }^{6}$

Berdasarkan ilustrasi di atas, korupsi adalah tindakan kejahatan yang dilakukan oleh manusia, baik dalam sektor publik ataupun swasta, demi kepentingan pribadi yang dapat merugikan negara dan masyarakat umum. Kerugian tersebut ada yang bersifat langsung seperti kerugian yang bersifat ekonomis:uang dan kekayaan yang diraup oleh para koruptor, juga ada yang bersifat tidak langsung seperti kebijakan-kebijakan yang dibuat oleh oknum tertentu yang merugikan masyarakat umum, seperti pungutan liar

\footnotetext{
${ }^{4}$ Abdullah Hehamahua, Jihad Memberantas Korusi,..h. 1

${ }^{5}$ Bibit S. Rianto dan Nurlis E.Meuko, Koruptor, Go to Hell!, Mengupas Anatomi Korupsi di Indonesia, cet.I (Jakarta: HIkmah, 2009), h.14.

${ }^{6}$ Dharma Kesuma dkk, Korupsi dan Pendidikan Antikorupsi, cet.I ( Bandung: Pustaka Aulia Press, 2008), h.13.
} 
"pungli". Begitupula tindakan pejabat yang menerima sogokan seperti hadiah dengan maksud tertentu. ${ }^{7}$

Dengan demikian, dapat diklasifikasikan secara garis besar bahwa korupsi ada dua kategori. Korupsi yang terjadi dalam bidang admistratif dan korupsi yang bersifat struktural. Yang pertama adalah praktek yang dilakukan oleh pegawai pemerintan atau pejabat Negara. Sedangkan yang bersifat struktural adalah tindakan korupsi yang dilakukan oleh orang yang dekat dengan pihak pemerintahan dengan masyarakat biasa dengan melakukan kesepakatan demi keuntungan pribadi keduanya. ${ }^{8}$ Sementara Shar J. Kpundeh (1997) mengatakan bahwa tipologi korupsi bisa disederhanakan kepada tiga bentuk. Pertama, korupsi incidental, adalah penyalahgunaan uang atau kekayaan yang berskala kecil yang dilakukan oleh pejabat rendah, individu atau kelompok kecil yang oportunis; kedua korupsi sistematik, penyalahgunaan berskala besar melalui tender public, penjualan kekayaan public, persuapan politis, yang mana pelakunya adalah para pejabat publik, politisi, elit birokrat, pebisnis; ketiga, korupsi sistemik penyalahgunaan yang berskala besar melalui "ghost worker" (pekerja hantu) pada daftar gaji pemerintahan. Ataupun pembayaran barang-barang fiktif. Bentuk kejahatan tersebut melibatkan elit birokrat, politisi, pebisnis. ${ }^{9}$

Menurut Dharma Kesuma dkk. bahwa melalui tipologi korupsi di atas, Indonesia bisa dikatakan telah dan sedang melewati ketiga tahap di atas. Korupsi incidental tidak dipertanyakan lagi bagaimana praktek tersebut merajalela dalam pemerintahan yang

${ }^{7}$ Erika Revida, MS., Korupsi di Indonesia: Masalah dan solusinya. http://repository.usu.ac.id/bitstream/123456789/3800/1/fisip-erika1.pdf. diakses hari Ahad, 29 Agustus 2017.

${ }^{8}$ Hakim Muda Harahap, Ayat-ayat Korupsi,.h.17-20.

${ }^{9}$ Dharma Kesuma dkk, Korupsi dan Pendidikan Antikorupsi,..h.42-43. 


\section{4 |RAusYan FiKR, Vol. 13 No.1 Juni 2017: 49-72}

berskala kecil, misalnya ditingkat desa ataupun camat. Yang kedua korupsi sistematik, sama dengan yang pertama tindak korupsi terjadi sangat terorganisir sehingga susah untuk mengungkapnya. Sementara tipe yang ketiga korupsi sistemik adalah korupsi yang terjadi dimana-mana serta sudah menjadi bagian dari system. Hampir sulit menemukan system pemerintahan yang bersih dari praktek korupsi. Meski mereka sadar bahwa tindakan yang mereka ambil sudah bertentangan dengan norma hukum, namun seakanakan hal itu sudah menjadi bagian tak terpisahkan untuk menjalankan tugas di kantor pemerintahan. ${ }^{10}$

Melihat kenyataan di atas, kondisi negara ini sudah sangat darurat korupsi. Setiap hari kita dipertontongkan oleh kasus korupsi yang melibatkan para pegawai, elit politik bahkan wakil rakyat dan walikota yang mereka itu seharusnya memberi contoh dan mengayomi masyarakat dengan pengabdian tanpa pamrih. Namun, realitas di lapangan justru sangat mengecewakan masyarakat. Pelaku korupsi (koruptor) tidak mendapat hukuman yang menjerahkan. Bahkan sering terjadi korupsi kolektif, yang mana melibatkan banyak oknum pemerintah. Sehingga, persoalan tersebut sulit sekali untuk diungkap atau diselesaikan sesuai dengan harapan. Kekuatan hukum terasa tumpul dihadapan mereka. Konsekuensinya adalah masyarakat mulai tidak percaya lagi terhadap para pemegang otoritas di pemerintahan. Ditambah lagi kemiskinan dan pengangguran semakin melilit bangsa ini.

Jika korupsi seperti di atas dibiarkan terus menerus akan berdampak pada kehidupan kesejarteraan masyarakat bawah. Sebagaimana dikatakan oleh Dhama kesuma dkk bahwa dampak korupsi, diantaranya adalah pertama, merosotnya kualitas pendidikan. Rendahnya pendidikan erat kaitannya dengan kwalitas para guru-guru yang menempati jabatan PNS. Di Indonesia budaya

\footnotetext{
${ }^{10}$ Dharma Kesuma dkk, Korupsi dan Pendidikan Antikorupsi,..h.45-46.
} 
nepotisme masih sangat kuat sekali. Kondisi demikian semakin diperburuk oleh bobroknya perlengkapan pendidikan khususnya di daerah terpencil. Kedua, ketidakadilan social, ${ }^{11}$ yang mana orang kaya semakin kaya dan orang miskin semakin miskin. Uang hanya dimonopoli oleh sebagian kelompok yang beruang dan punya kekuatan di pemerintahan. Kondisi ini akan berdampak secara tidak langsung kepada busung lapar dan kematian. Orang miskin tidak berani berobat kerumah sakit karena ketidakmampuan membayar segala biaya admistrasi dan obat. Realitas demikian hasil dari ulah para koruptor yang menyalahgunakan biaya atau uang yang seharusnya diberikan kepada mereka. Dan ketiga adalah menghambat pembangunan nasional. Hal itu dibenarkan oleh Ibnu Khaldun dalam Mukaddimahnya dengan bahasan bahwa kedzaliman korupsi dapat menggoncang stabilitas nasional. ${ }^{12}$

\section{Terma Korupsi dalam Al-Quran}

Korupsi bisa dikatekorigan sebagai kedzaliman sosial. Terma korupsi sendiri telah disinggung oleh Ibnu Khaldun dalam mukaddimahnya dengan kata dzalim. Menurutnya kata dzalim tidak hanya berarti mengambil harta orang lain tanpa sebab dan alasan, tapi lebih daripada itu. Termasuk di dalamnya adalah setiap orang yang mengambil harta seseorang, merampoknya ataupun merasa berhak kepada harta tersebut padahal tidak diizinkan secara hukum. Ataupun menghalangi hak-hak orang lain juga termasuk dzalim (korupsi). Yang pada akhirnya akan merusak kemakmuran dan pembangunan nasional karena hilangnya rasa optimis dari rakyat untuk bekerja. ${ }^{13}$

\footnotetext{
${ }^{11}$ Dharma Kesuma dkk, Korupsi dan Pendidikan Antikorupsi,..h.33-34.

12 Abdul Rahman Ibnu Khaldun, Mukaddimah Ibn Khaldun, cet.IX ( Beirut: Dar. al-Kutub al-Ilmiah, 2006), h.224.

${ }^{13}$ Abdul Rahman Ibnu Khaldun, Mukaddimah Ibn Khaldun, cet.IX ( Beirut: Dar. al-Kutub al-Ilmiah, 2006), h. 225.
} 
Al Quran sebagaimana diyakini sebagai kitab yang membawa angin perubahan sosial. Maka secara pasti ia tak luput dari ulasan yang menyinggung baik secara langsung maupun tidak langsung tentang keadilan social. Bahkan terma keadilan merupakan salah satu maqashid Al Quran menurut Said Nursi. ${ }^{14}$ Dengan demikian dapat dipahami bahwa ketidakadilan juga merupakan persoalan yang tidak luput dari pembahasan dalam al-Quran.

Dalam Al Quran sebenarnya banyak kata menunjuk pada makna korupsi secara langsung maupun tidak langsung. Hakim Muda Harahap dalam Ayat-ayat Korupsi menyebutkan beberapa terma yang sepadan dengan arti korupsi, diantaranya adalah gulul, al-suht, harbu/fasad, al-sariqah, al-dalwu dan gasab. ${ }^{15}$

\section{a) Terma Pengkhianatan (gulul)}

Kosa kata gulul direkam dalam surah Ali Imran ayat 161 sebagai berikut,

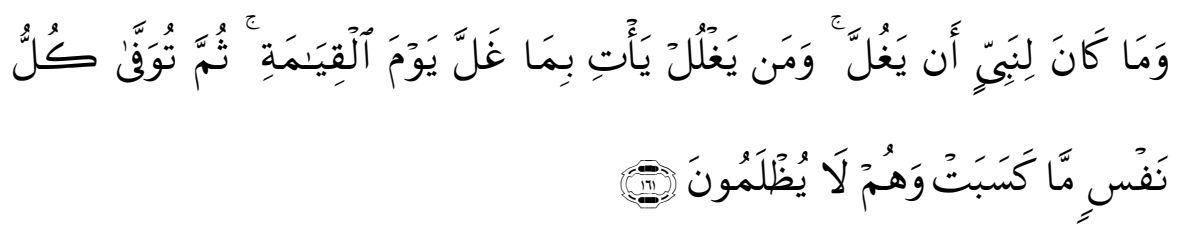

Terjemahannya:

Tidak mungkin seorang nabi berkhianat dalam urusan harta rampasan perang. barangsiapa yang berkhianat dalam urusan rampasan perang itu, Maka pada hari kiamat ia akan datang membawa apa yang dikhianatkannya itu, Kemudian tiap-tiap diri akan diberi pembalasan tentang apa yang ia kerjakan dengan (pembalasan) setimpal, sedang mereka tidak dianiaya (Ali Imran: 161).

Dalam ayat di atas kata kunci yang bisa dipahami sepadan dengan korupsi adalah galla. Menurut Mujam Maqayiis al-lughah, galla

${ }^{14}$ Badiuzzaman Said Nursi, Isyarat al-Ijaz fi Madzan al-Ijaz, ditahkik oleh Ihsan Kasim Salim, cet.IV (Kairo: Sozler Publication, 2008), h. 23.

${ }^{15}$ Hakim Muda Harahap, Ayat-ayat Korupsi,.h. 50. 
berarti thallala al-syai dan jika berbentuk al-gulul berarti an yakhfa al-syai, menyembunyikan sesuatu. Sedangkan hadis Nabi la iglal wa la islal berarti al-khiyanah (penghianatan). ${ }^{16}$ Hal itu senada dengan pandangan Fakhruddin ar-Razi dalam Mafatih al-Gaib ketika membahas ayat tersebut bahwa kata gulul: berarti alkhiyanat, pengkhiantan. Yaitu akhaza al-syai fi khafyatin, mengambil sesuatu dengan sembunyi-sembunyi. ${ }^{17}$ Dari segi bahasa ayat di atas memang berbicara masalah penipuan dan pengkhianatan yang terjadi pada masa itu. Hal itu dikuatkan dari sebab turunnya ayat di atas. Fakhruddin ar-Razi menyebutkan beberapa pendapat dan riwayat terkait dengan sebab turunnya ayat tersebut, misalnya riwayat Ikrimah dan Said bin Jubair mengatakan bahwa ayat tersebut turun pada hilangnya permadani merah ketika perang badar, kemudian sebagian orang munafik menuduh Nabi Muhammad yang mengambilnya. Sementara riwayat dari Muqatil dan al-Kalabi menyatakan bahwa ayat ini turun kepada pemanah yang meninggalkan markas mereka karena takut tidak mendapat bagian harta ghanimah (rampasan) pada perang Uhud. ${ }^{18}$ Dalam riwayat tersebut terkesan ada kekhawatiran sebagian sahabat barang ghanimah tidak dibagikan kepada mereka sampai-sampai Nabi Saw. Mengatakan "kalian kira kami menyembunyikan dan tidak membagikan harta rampasan itu?". Maka turunlah ayat di atas.

Dari riwayat di atas, mesti banyak versi namun tidak keluar dari makna pengkhianatan, ketidakjujuran baik yang dialamatkan kepada Rasulullah Saw. Atapun kepada sahabat yang menyembunyikan sebagian harta warisan sebelum dibagi. Pada

${ }^{16}$ Abi Husain Ahmad Ibnu Faris, Mujam Maqais al-Lugha, ditahkik Abdul Salam Muhammad Harun, Juz, IV, (Beirut: Dar. Al-Fikri, t.p.t.t), kitab ghain, h. 375-376.

${ }^{17}$ Fakhruddin Ar-Razi, Mafatihul al-Ghaib, cet.I, juz IX, (Beirut: Dar. Al-Fikr, 1981), h.71.

${ }^{18}$ Fakhruddin Ar-Razi, Mafatihul al-Ghaib, cet.I, juz IX, (Beirut: Dar. Al-Fikr, 1981), h.72. 
intinya, dalam ayat tersebut mensinyalir terjadi ketidakjujuran pada persoalan harta. Sehingga, erat kaitannya dengan korupsi dewasa ini. Yaitu yaitu penggelapan uang rakyat oleh para koruptor. Hal itu bisa dikategorikan korupsi otogenik (otogenic corruption), korupsi yang dilakukan oleh perorangan dengan tidak melibatkan orang lain, semisal mencuri, mengambil uang negara, serta penyalahgunaan fasilitas negara demi kepentingan pribadi.

\section{b). Terma Penyuapan (as-suhtu)}

Terma as-suhtu terekam dalam QS. Al-Maidah: 42

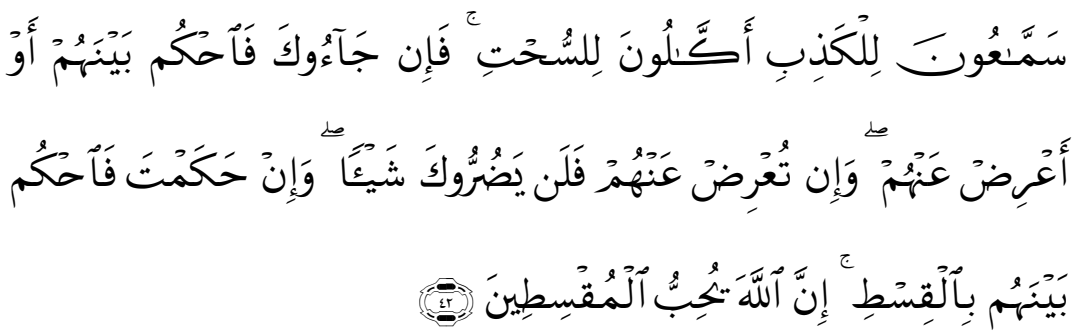

Terjemahannya:

Mereka itu adalah orang-orang yang suka mendengar berita bohong, banyak memakan yang haram. jika mereka (orang Yahudi) datang kepadamu (untuk meminta putusan), Maka put uskanlah (perkara itu) diantara mereka, atau berpalinglah dari mereka; jika kamu berpaling dari mereka Maka mereka tidak akan memberi mudharat kepadamu sedikitpun. dan jika kamu memutuskan perkara mereka, Maka putuskanlah (perkara itu) diantara mereka dengan adil, Sesungguhnya Allah menyukai orang-orang yang adil. (QS. Al-Maidah: 42).

Kata kunci pada ayat di atas adalah "al-suhtu". Imama alTabari dalam menyebutkan beberapa riwayat arti dari kata tersebut, dan semuanya menunjukkan pada 'risywah" sogokan yang 
dilakukan oleh orang yahudi kepada hakim mereka. ${ }^{19}$ Senada dengan Az-Zamakhsyari dalam al-Kasysyafnya, bahwa "al-suhtu" adalah segala sesuatu yang haram diambil (dimakan). Menurutnya dalam tradisi Bani Israil mereka memakan sogokan dan menghalalkan yang haram serta memutuskan perkara dengan mengutamakan kepentingan orang yang memberikan risywah (suap) serta mengabaikan kepentingan lawannya. ${ }^{20}$ Hal itu senada dengan pandangan Fakhuruddin al-Razi yang mengutip pandangan ahli bahasa, (a) al-Zujjaj: istasalahu, menghabisi sampai akarnya, (b) alLaits: segala sesuatu yang haram; (c) al-Farra: syiddatu al-jui, sangat lapar: menghabisi segala yang ada. Tindakan tersebut, menutut penulis, erat kaitannya makna bahasa di atas dimana seorang penyogok akan akan membuat hukum tidak berakar pada keadilan karena yang disogok sangat rakus dengan uang haram tersebut. Sehingga al-Suhtu adalah sokokan kepada hakim agar mereka berpihak kepada kepentingannya. ${ }^{21}$ Sementara Ibnu Asyur lebih luas melihat kata al-Suhtu di atas. Mencakup segala harta yang haram: sogokan, riba, makan harta anak yatim dan barang rampasan. $^{22}$

Berdasarkan dari pemaparan di atas, bisa diambil benang merah bahwa kata"al-suhtu" dalam ayat tersebut menandaskan terjadinya suap kepada penegak hukum demi meringankan hukuman ataupun membuat hakim bersikap tidak adil (berat sebelah pada dua orang berperkara) melalui suapan tersebut. Suap atau uang komisi

${ }^{19}$ Ibnu Juraij at-Tabari, Tafsir al-Tabari, Jami al-Bayan an Tawil ae alQuran ditahkik Mahmud Muhammad Syakir, juz x (Kairo: Maktabah Ibnu Taimiyah, t.t), h.319.

${ }^{20}$ Az-Zamakhsyari, al-Kasysyaf an Haqaid Guwamid al-Tanzil wa Uyun al-Tanzil fi Wujuh al-Tawil, ditahkik Adil Ahmad Abdul Maujud,cet I, juz II (Riyad: Maktabah al-Abikan,1998), h. 237-238.

${ }^{21}$ Fakhruddin Ar-Razi, Mafatihul al-Ghaib..juz. XI, h.241.

${ }^{22}$ Muhammad al-Tahir Ibnu Asyur, Al-Tahrir wa al-Tanwir, juz, VI ( Tunis: Al-Sadad al-Tunisa, 1984), h.. 202 
sebagaimana telah disebutkan termasuk bagian dari bentuk korupsi investif (investive corruption). Untuk bentuk korupsi tersebut, di Indonesia sangatlah marak terjadi di seluruh elemen pemerintahan. Bentuk korupsi ini biasanya juga disebut uang pelicin, untuk melancarkan suatu urusan dengan melangar melalui aturan-aturan tertentu.

\section{c) Terma perampokan dan perusakan (harb dan fasada)}

Kedua term di atas teremakam dalam satu surah secara bersamaan yaitu, Al-Maidah: 33

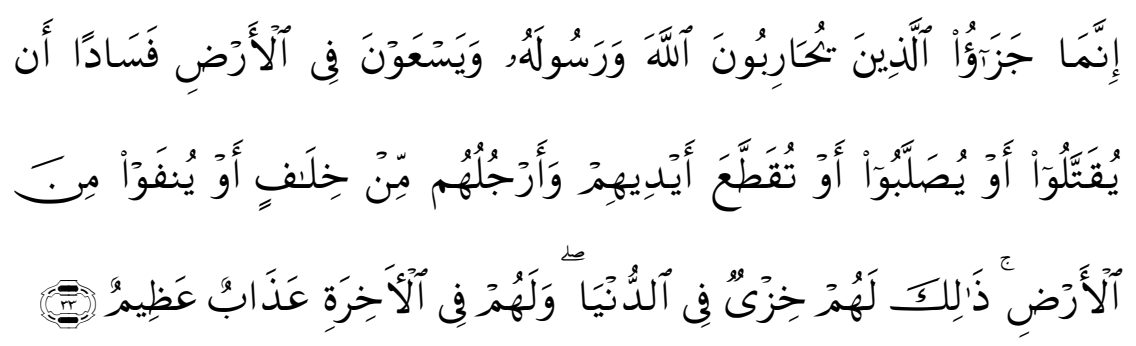

Terjemahannya:

"Sesungguhnya pembalasan terhadap orang-orang yang memerangi Allah dan rasul-Nya dan membuat kerusakan di muka bumi, hanyalah mereka dibunuh atau disalib, atau dipotong tangan dan kaki mereka dengan bertimbal balik atau dibuang dari negeri (tempat kediamannya). yang demikian itu (sebagai) suatu penghinaan untuk mereka didunia, dan di akhirat mereka beroleh siksaan yang besar, (QS. Al-Maidah: 33)

Dalam ayat di atas, yang menjadi kata kunci adalah "yuharibunallaha wa rasulahu" dan "wayasaun fi al-adhi fasada". Kata "haaraba" biasa diartikan sebagai berperang, namun Fakhrudin al-Razi melihat kata tersebut tidak cocok dinisbahkan kepada Allah meski bisa pada Rasulullah. Sehingga, menurutnya kata tersebut tidak diartikan sebagai memerangi Allah melainkan melanggar 
aturan dan hukum Allah dan Rasul-Nya. ${ }^{23}$ Masih menurut al-Razi, yang dimaksud dengan al-muharibun pada ayat di atas adalah gerombolan manusia atau perampok yang mengancam keamanan jiwa orang muslim. Hal itu sesuai dengan sebab turunya ayat tersebut sebagaimana yang disebutkan oleh an-Naisaburi bahwa sekelompok orang dari kaum bani Uklin dan Urainah masuk Islam kemudian tidak betah tinggal di Madinah maka Rasulullah memberikan beberapa ekor unta supaya mereka minum susunya di luar kota, tapi mereka membelok dengan membunuh para pengembala yang menemaninya dan mengambil lari unta tersebut. Maka Rasulullah mengutus sahabat untuk mengejar mereka, dan akhirnya sahabat tersebut memotong tangan dan mencungkil mata mereka. Mereka tinggalkan di Harrah sampai mati. ${ }^{24}$

Dari penjelasan di atas memberikan gambaran bahwa muharib yang dimaksud di atas adalah kelompok yang mengancam keamanan social maupun jiwa dengan merampas harta demi memenuhi nafsu keserakahan mereka. Dengan demikian jika dikaitkan dengan kasus korupsi dewasa ini, banyak kesamaan meski caranya berbeda. Jika mereka merampas harta secara paksa dan terang-terangan di jalanan. Para koruptor sekarang juga merampas uang rakyat ataupun uang negara dengan cara illegal namun lebih halus dan terorganisir. ${ }^{25}$ Meski demikian, secara hakikat sama, karena sama-sama merugikan orang banyak demi pemuasan nafsu mereka. Bentuk korupsi semacam ini adalah korupsi otogenik (autogenic corruption), korupsi yang dilakukan sendiri tanpa melibatkan orang lain semisal mencuri, menggunakan uang negara tidak tepat, tidak menjalankan tugas, memalsukan dokumen,

${ }^{23}$ Fakhruddin Ar-Razi, Mafatihul al-Ghaib..juz. XI, h.220.

${ }^{24}$ Abu Hasan al-Wahidi an-Naisaburi, Asbabul al-Nuzul, (Kairo: Dar. AlTaqwa, 2005), hal.119/ lihat juga Imam at-Tabari, Tafsir al-Tabari, juz X, h.245.

${ }^{25}$ Hakim Muda Harahap, Ayat-ayat Korupsi,.h. 75. 
menggelapkan uang pajak, menggunakan informasi internal dan informasi rahasia untuk kepentingan pribadi dsb.

Adapun kata kunci kedua adalah "wayasaun fi al-adhi fasada". Kata "fasada", dalam ayat itu diartikan kerusakan. Dalam al-Mufradat fi Garib Al Qurandikatakan khuruju al-sayi an al-itidal, keluarnya sesuatu dari garis keseimbangan. Lawan kata dari asSalah, kebaikan. Kata tersebut bisa dipakai pada kerusakan pada jiwa, badan dan segala sesuatu yang keluar dari garis istiqamah. ${ }^{26}$ Dalam pandangan Ibnu Asyur, al-fasad adalah merusak atau menghancurkan jiwa dan harta. ${ }^{27}$ Dalam ayat lain Q.S. Ar-Rum; 41 "telah tampak kerusakan di darat dan di laut disebabkan karena perbuatan tangan manusia (QS. Ar-Rum:41)". Dalam ayat tersebut disebutkan bahwa kerusakan di muka bumi ini (darat dan laut) adalah hasil ulah tangan manusia. Pemahaman "ulah tangan manusia" di sini bisa diterjemahkan dengan kekuatan dan otoritas. Dalam hal ini para pebabat publik menyalahgunakan jabatan dan otoritas yang diamanahkan oleh rakyat.

Melalui arti sederhana dari kata tersebut sudah dimengerti korelasi antara kata fasad dengan koruspi. Korupsi secara umum tak lain kecuali merusak dan menyalahgunakan harta atau uang negara yang notabene uang seluruh rakyat menjadi uang milik pribadi. Merusak jiwa adalah dampak dari korupsi tersebut. Dimana uang yang seharusnya dipakai oleh negara untuk meningkatkan kesejahteraan rakyat melalui pelayanan kesehatan dan pendidikan yang baik, justru dinikmati oleh segelintir orang atau koruptor. Konsekwensi logis dari realitas ini adalah terjadinya busung lapar dan kemiskinan yang semakin melilit bangsa ini. Hal itu tak bisa

${ }^{26}$ Al-Ragib al-Asfahani, al-Mufradat fi Garib al-Quran,(Beirut: Dar. AlMarifat, t.t), kitab fau

${ }^{27}$ Muhammad al-Tahir Ibnu Asyur, Al-Tahrir wa al-Tanwir,. Juz VI, h. 183 . 
dipisahkan dari rendahnya sumber daya manusia karena pendidikan yang minim.

\section{Hukuman Para Koruptor}

Memberantas korupsi memang bukan persoalan yang ringan. Bahkan bisa dikatakan sebagai jihad melawan kedzaliman dalam dewasa ini. Nyatanya, undang-undang negara ternyata juga belum cukup bisa mengurangi dan menjerahkan para koruptor. Tentu hal itu tidak lepas dari beberapa unsur yang saling terkait. Di antaranya adalah sistem itu sendiri, pemerintah yang tegas dan transparan dan masyarakat yang sadar hukum. Demikian beberapa unsur yang mesrti diperjuangkan. Dan menuju kesana membutuhkan proses dan kesabaran melalui pendidikan sejak dini terhadap generasi muda. Termasuk untuk menanamkan nilai-nilai kejujuran kepada mereka. Itu adalah langkah preventif yang mesti dilakukan sekarang ini. Adapun menyikapi para koruptor yang banyak 'gentayangan' sekarang, dibutuhkan transparansi seluruh sektor pemerintahan, serta bersikap tegas terhadap pelaku koruptor dengan mencoba hukum mati khususnya koruptor kelas kakap.

Hukuman berat itu dapat dipertimbangkan setelah hokum jera lainya tidak efektif. Karena dampak korupsi di Indonesia sangatlah besar, apalagi angka kemiskinan dan bencana alam yang akhir-akhir ini melanda nusantara. Dalam kondisi demikian semakin mendesak para penegak hukum untuk serius mengungkap semua kasus korupsi, tanpa memandang bulu. Hukum harus ditegakkan. Cara penjerahan yang keras harus dicoba demi kepentingan umum, demi stablitas nasional. Indonesia rentang sekali terjadi konflik antar etnis, agama dan lain sebagainya. Menurut Jusuf Kalla factor ekonomi salah satu pemicu kejadian tersebut. Yaitu terjadinya ketidakdilan social dalam masyarakat. Ketidakadilan tersebut erat kaitannya dengan korupsi. 
Wacana hukum mati dan memiskinkan koruptor pun kembali hangat lagi sebagai hukuman penjerahan bagi koruptor yang lain. Hifdzil Alim SH, peneliti Pusat Kajian Antikorupsi Universitas Gadjah Mada Yogyakarta, bahwa hukum mati bagi koruptor adalah harus dilakukan karena korupsi termasuk kejahatan luar biasa karena bagian dari pencurian, perampokan, dan penjajahan terhadap hak seluruh rakyat Indonesia. Dan hukuman itu tidak melanggat HAM karena pelaku korupsi atau koruptor melanggar hak asasi manusia (HAM) sendiri. Karena korupsi sendiri secara perlahanlahan membunuh jutaan penduduk Indonesia. "Teroris yang meledakkan bom Bali I dan membunuh sekitar 200 orang saja divonis hukuman mati, kenapa koruptor yang membunuh jutaan orang tidak bisa dihukum mati. Padahal terorisme dan korupsi merupakan tindak kejahatan luar biasa," demikian tandasnya. Ia kemudian mengatakan, bahwa UU Nomor 31 Tahun 1999 yang diamendemen menjadi UU Nomor 20 Tahun 2001 tentang pemberantasan tindak pidana korupsi, memungkinkan pelaku korupsi di negeri ini untuk dijatuhi hukuman mati. ${ }^{28}$

Tidak jauh berbeda pendapat Menteri Hukum dan HAM Patrialis Akbar menyatakan hukuman mati bagi para koruptor secara normatif sudah bisa diberlakukan di Indonesia. Menurutnya vonis hukum mati bagi koruptor bisa sekali diterapkan apalagi jika Negara sedang dilanda bencana alam sementara para koruptor seenaknya meraup uang negara ${ }^{29}$.

Demikian sejumlah pandangan pakar tentang hukum mati bagi koruptor. Sementara dalam Al Quran persoalan tersebut sebenarnya juga ada indikasi kesana. Sebagaimana telah disinggung sebelumnya bahwa keadilan adalah salah satu pesan universal $\mathrm{Al}$

\footnotetext{
Agustus 2017

${ }^{29}$ http://kamushukum.com/en/hukuman-mati-bagi-koruptor-bisaditerapkan diakses hari Selasa, 29 Agustus 2017
}

${ }^{28} \mathrm{http}$ ://antaranews.com/berita/1271230582 diakses hari Selasa, 29 
Quran yang mesti diperhatian dalam memahaminya. Al Quran sebagai pembebas dari ketidakadilan. Apalagi yang berkaitan dengan harta, sejumlah ayat mewanti-wanti manusia untuk makan harta secara halalan tayyibah (QS. Al-Baqarah: 168), (al-Maidah: 88) dan tidak makan secara bathil (QS. Al-Baqarah: 188) dan QS. An-Nisa: 29). Ayat-ayat di atas secara tersirat mengecam tindakan korupsi yang mendapatkan harta secata illegal, dan memakan harta haram. ${ }^{30}$ Hanya saja ayat diatas tidak ada secara tegas mengatakan bahwa korupsi merupakan tindak pidana yang harus divonis mati. Dalam kasus pencurian hanya dihukum potong tangan sebagaimana dalam surah al-Maidah: 38 .
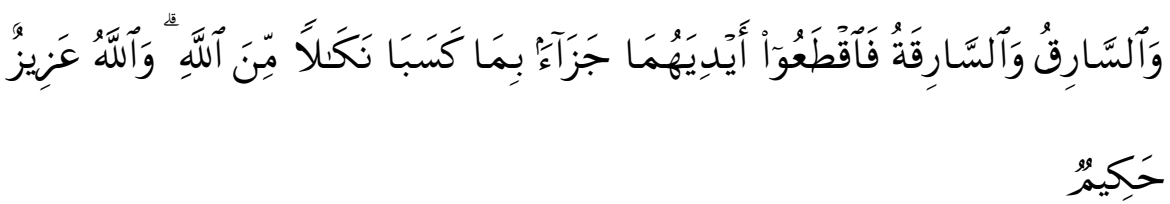

Terjemahannya:

Laki-laki yang mencuri dan perempuan yang mencuri, potonglah tangan keduanya (sebagai) pembalasan bagi apa yang mereka kerjakan dan sebagai siksaan dari Allah. dan Allah Maha Perkasa lagi Maha Bijaksana.

Sementara ayat yang memungkinkan sebagai landasan hukuman mati adalah ayat tentang perampokan. Dan saya kira korupsi yang kelas kakap sudah masuk kategori perampokan yang meresahkan masyarakat dan mengganggu keamanan nasional. Dalam Surah al-Maidah ayat: 33

${ }^{30}$ Yunahar Ilyas, Cakrawala al-Quran, tafsir tematis tentang berbagai aspek kehidupan, cet. II, (Yogyakarta: Itqan Publishing, 2009), hal. 212. 


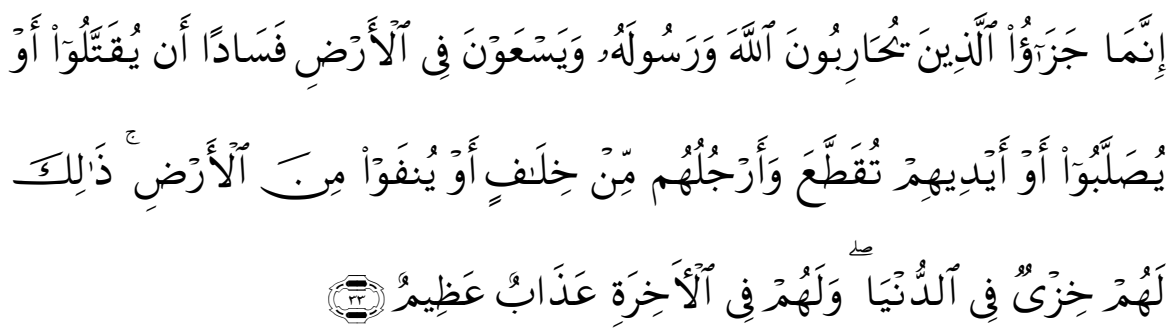

Terjemahannya:

"Sesungguhnya pembalasan terhadap orang-orang yang memerangi Allah dan rasul-Nya dan membuat kerusakan di muka bumi, hanyalah mereka dibunuh atau disalib, atau dipotong tangan dan kaki mereka dengan bertimbal balik atau dibuang dari negeri (tempat kediamannya). yang demikian itu (sebagai) suatu penghinaan untuk mereka didunia, dan di akhirat mereka beroleh siksaan yang besar, (QS. Al-Maidah: 33)

Ayat di atas sesuai dengan beberapa riwayat menyatakan bahwa turun pada persoalan muharabah, perampokan atau qathu althariq. Di samping itu, tidak hanya melakukan perampokan dengan merampas dan membunuh orang di tengah jalan, tapi juga melakukan kerusakan di muka bumi ini. Kedua kejahatan tersebut dalam lanjutan ayat tersebut terdapat beberapa hukuman. Yaitu, dibunuh, disalib, atau diasingkan. Perbedaan penafsiran pada kata awu juga berdampak pada pemahaman mereka terhadap hukuman tersebut. Apakah li takhyir, pilihan, hukuman diserahkan pada hakim. Sebagaimana salah satu riwayat Ibnu Abbas, Alin bin Thalhah, Said bin Musayyab dan Mujahid bahwa Imam (penegak hukum) bisa memilih salah satu hukuman di atas. Sementara dalam riwayat lain dikatakan li al-bayan, penjelasan: yaitu hukuman sesuai dengan jenis kejahatan pelaku. Jika membunuh maka dibunuh, jika membunuh dan mengambil harta maka dibunuh dan disalib. Jika hanya mengambil harta maka potong tangan dan kaki secara silang, 
dan jika hanya menakut-nakuti di tengah jalan maka di asingkan. Demikian pandangan mayoritas ulama kata Fakruddin ar-Razi. ${ }^{31}$

Terkait dengan kasus korupsi, hukuman korupsi tentu juga berbeda-beda. Sesuai dengan tingkat kejahatan dalam hal ini bentuk korupsi yang dilakukan. Namun jika bentuk korupsinya sudah terbilang besar: misalnya menggoyahkan stabilitas nasional apalagi dalam keadaan bencana alam, maka sesuai dengan undang-undang nomor 20 tahun 2010, hukum mati bagi koruptor menjadi suatu kemestian. Mengingat hukum penjara yang selama ini diterapkan di Indonesia tidak cukup berpengaruh dalam mengatasi kasus korupsi. Malah semakin hari semakin banyak kasus yang terungkap tapi tidak juga bisa membasmi sampai akar-karnya.

Berangkat dari realitas di atas, penulis mencoba memahami QS. Al-Baqarah: 33 dengan pendekatan tafsir maqashidi. ${ }^{32}$ Yaitu tafsir yang berangkat dari dialektika teks dan realita ${ }^{33}$ dalam mencapai tujuan Tuhan dalam al-Quran: yang salah satunya adalah membumikan konsep keadilan di muka bumi ini, sebagaimana

${ }^{31}$ Fakhruddin Ar-Razi, Mafatihul al-Ghaib..juz. XI, h.221.

${ }^{32}$ Tafsir yang berangkat nilai-nilai universal al-Quran, dalam pandangan Nursi, yaitu ketuhanan, kenabian, keadilan dan hari kebangkitan (Isyarat alIjaz.hal.23.) sementara Ibnu Asyur berangkat dari konsep Fitrah yang kemudian melahirkan nilai universal misalnya as-samahah (egalitarianisme) wa al-adl (keadilan) dan al-hurriyah (kebebasan). Lihat. Muhammad Tahir Ibnu Asyur, dithakik Muhammad Thahir al-Misawi, Maqashid as-Syariah al-Islamiyah,cet.II (Bairut: Dar. Nafais, 2001), h.268.

${ }^{33}$ Dalam isitlilah as-Syatibi: seorang mujtahid dalam menelorkan hukum harus melakukan tahqiq al-manat: tahqiq adalah upaya untuk mengidentifikasi satu masalah, sedangkan manat adalah objek penerapan hukum. Sehingga, tahqiq al-manat adalah upaya seorang mujtahid untuk mengidentifikasi dan menverifikasi subtansi objek hukum, untuk menghindari terjadinya kesalahan teksnis dalam menyesuaikan antara hukum dan objek. Lihat (Rauf Amin, Jurnal pemikiran PINISI, edisi: 22 Vol.XIV Oktober 2004, h. 153. 
pandangan Said Nursi dan Ibnu Asyur ${ }^{34}$ dengan selalu mempertimbangkan al-Darururyat al-Khmasah: agama, jiwa, nasal, harta, akal. ${ }^{35}$

Maka penerapan hukum mati bagi koruptor bisa sekali diterapkan melalui pemahaman maqashidi terhadap ayat di atas. Perampokan dengan membunuh yang dimaksud ayat tersebut sama halnya tindakan perampokan yang dilakukan oleh para koruptor di negara ini. Motif dan dampaknya sama. Hanya cara dan bentuknya berbeda. Motiv perampokan yang pada masa Nabi tak lain adalah kerasukan terhadap harta dengan menghalalkan segala cara termasuk membunuh demi kepuasan hawa nafsu (kepentingan pribadi). Sama halnya dengan pelaku koruptor yang meraup uang negara karena kerakusan yang juga hanya kepentingan pribadi. Adapun, dampak dari kedua kejahatan tersebut sama-sama merusak tatanan dan stabilitas nasional, yang dalam bahasa Abdullah Hehamahuna telah menimbulkan kerusakan (Sumber Daya Alam, Sumber Daya Manusia, dan tatanan masyarakat). ${ }^{36}$

Adapun cara dan bentuk keduannya yang berbeda hanya dari perbedaan luar. Kalau perampokan yang terjadi dulu yang dikenal dengan qathu al-tariq, melakukan perampasan dan kejahatan secara terang-terangan, misalnya membunuh korban secara langsung dan merampas harta mereka. Sementara koruptor bermain di balik layar secara sembunyi-sembunyi, terorganisir secara baik. Namun keduanya tetap merugikan negara dan masyarakat umum. Kalau perampok membunuh secara langsung sehingga wajib diqishas, maka sangatlah wajar dan pantas jika koruptor juga diqisahs karena telah membunuh secara perlahan jutaan masyarakat secara tidak

\footnotetext{
${ }^{34}$ Badiuzzaman Said Nursi, Isyarat al-Ijaz..hal.23./ Muhammad Tahir Ibnu Asyur...hal.268.

35 Ahmad Raisuni, Nazhariyat al-Maqashid Inda al-Iman as-Syatibi (alMahad al-Alami li al-Fikri al-Islami), Edisi I, thn, 1981.h.139-146.

${ }^{36}$ Abdullah Hehamahua, Jihad Memberantas Korusi,..h. 2
} 
langsung. Bahkan korupsi termasuk salah satu pemicu terjadinya konfilik dan tawuran yang memakan korban karena tidak adanya keadilan sosial dalam masyarakat.

Semenrtara dalam hadis, ada beberapa data yang mengecam kasus penipuan (korupsi), misalanya "man gassya fa laisa minni" siapa yang melakukan tipu daya atau manipulasi, maka bukan dari komunitas kami, alias kafir". H.R. Muslim. Dalam hadis lain dari Bukhari dari Abi Hurairah berkata; Nabi Saw. Beridiri sama kami, lalu beliau menyinggung masalah ghulul dan berkata:

"saya nanti menemui seseorang dari kamu pada hari kiamat, di atas bahunya ada kembing yang mengembek dan kuda yang meringkik. Orang itu berkata: Ya Rasulullah, tolonglah saya, tolonglah saya. Saya menjawab: Saya tidak dapat menolong kamu sedikitpun. Sesungguhnya saya pernah menyampaikan kepada engkau (atas haramnya perbuatan korupsi). ${ }^{37}$

Dengan demikian ada riwayat yang menyatakan bahwa Nabi tidak mengsalati pelaku korupsi yang meninggal karena saking besarnya dosa tersebut.

\section{Penutup}

Korupsi adalah tindak kejahatan dan kedzaliman yang sudah ada dalam al-Quran. Kejahatan tersebut harus diberantas karena kerena tidak sesuai dengan nilai luhur Al Quran dan Pancasila: keadialan sosial. Memberantas dan melalukan penjerahan terhadap para koruptor termasuk jihad fi sabilillah. Karena dampak korupsi telah mengancam stabilitas nasional, pendidikan ambruk serta semakin memiskinkan rakyat miskin. Inilah ketidakadilan dan fasad yang dilakukan oleh manusia dewasa ini. Pemeritah dalam

${ }^{37}$ Waryono Abdul Gafur, Hidup Bersama al-Quran, Jawaban al-Quran terhadap Problematika Sosial, cet. I (Yogyakarta, Pustaka Rihlah, 2007), h. 228. 
menghadapi kedzaliman tersebut diharuskan bersikap tegas sekaligus terbuka. Sistem hukum negara harus diperbaharui. Pendidikan korupsi sejak dini harus dimulai. Bahkan hukum mati bagi koruptor mesti dicoba demi kemaslahatan umum.

\section{Daftar Pustaka:}

Amin, Abdul Rauf, Jurnal pemikiran PINISI, edisi: 22 Vol.XIV Oktober 2004.

Ar-Razi, Fakhruddin, Mafatihul al-Ghaib, cet.I, juz IX, Beirut: Dar. Al-Fikr, 1981.

Asfahan, Al-Ragib al-i, al-Mufradat fi Garib al-Quran, Beirut: Dar. Al-Marifat, t.t.

Az-Zamakhsyari, al-Kasysyaf an Haqaid Guwamid al-Tanzil wa .Uyun al-Tanzil fi Wujuh al-Tawil, ditahkik Adil Ahmad Abdul Maujud,cet I, juz II, Riyad: Maktabah al-Abikan, 1998.

Gafur, Waryono Abdul, Hidup Bersama al-Quran, Jawaban Al Quranterhadap Problematika Sosial, cet. I, Yogyakarta, Pustaka Rihlah, 2007.

Harahap, Hakim Muda Ayat-ayat Korupsi, cet.I, Yogyakarta: Gama Media, 2009.

Ibnu Asyur, Muhammad al-Tahir, Al-Tahrir wa al-Tanwir, juz, VI , Tunis: Al-Sadad al-Tunisa, 1984

Misawi, Maqashid as-Syariah al-Islamiyah,cet. II,Bairut: Dar. Nafais, 2001. 
Ibnu Faris, Abi Husain Ahmad Mujam Maqais al-Lugha, ditahkik Abdul Salam Muhammad Harun, Juz, IV, Beirut: Dar. AlFikri, t.p.t.t.

Ibnu Khaldun, Abdul Rahman, Mukaddimah Ibn Khaldun, cet.IX. Beirut: Dar. al-Kutub al-Ilmiah, 2006.

Ilyas, Yunahar, Cakrawala al-Quran, tafsir tematis tentang berbagai aspek kehidupan, cet. II, Yogyakarta: Itqan Publishing, 2009.

Kesuma, Dharma dkk, Korupsi dan Pendidikan Antikorupsi, cet.I, Bandung: Pustaka Aulia Press, 2008.

Naisaburi Abu Hasan al-Wahidi an-, Asbabul al-Nuzul, Kairo: Dar. Al-Taqwa, 2005.

Nursi, Badiuzzaman Said Isyarat al-Ijaz fi Madzan al-Ijaz, ditahkik oleh Ihsan Kasim Salim, cet. IV , Kairo: Sozler Publication, 2008 .

Rianto, Bibit S. dan Nurlis E.Meuko, Koruptor, Go to Hell!, Mengupas Anatomi Korupsi di Indonesia, cet.I, Jakarta: HIkmah, 2009.

Raisuni Ahmad, Nazhariyat al-Maqashid_Inda al-Iman as-Syatibi (al-Mahad al-Alami li al-Fikri al-Islami), Edisi I, thn, 1981.

Tabari, Ibnu Juraij al-, Tafsir al-Tabari, Jami al-Bayan an Tawil ae Al Quranditahkik Mahmud Muhammad Syakir, juz X Kairo: Maktabah Ibnu Taimiyah, t.t. 
72 |RAuSyan FiKR, Vol. 13 No.1 Juni 2017: 49-72

\section{Google:}

http://antaranews.com/berita/1271230582

http://repository.usu.ac.id/bitstream/123456789/3800/1/fisiperika1.pdf.

//kabarntt.blogspot.com/2007/12/korupsi-sebab-danakibat 490. html

http://kamushukum.com/en/hukuman-mati-bagi-koruptor-bisaditerapkan 